\title{
Korkuyorum Anne'de Hegemonik Erkekliğin Yapı sökümü
}

\section{Ö. Nilay Erbalaban Gürbüz}

\author{
Gaziantep Üniversitesi Güzel Sanatlar Fakültesi \\ nilayerbalaban@hotmail.com
}

Öz

Toplumsal cinsiyet çalıșmaları 1970'li yıllardan itibaren 'erkeklik' ve kültürel yapılar arasındaki ilișkiye odaklanmaya bașlamıștır. Bu araștırmalar erkekliğin tek bir tanımı olamayacağını ve erkeklik tanımının toplumsal iktidar ilișkileriyle iç içe geçtiğini göstermiștir. Türkiye sinemasında 2000'li yılların bașından itibaren farklı 'erkeklik' temsilleri yer almaya bașlamıștır. Bu erkek karakterler toplumsal cinsiyete ait geleneksel rollerin dıșında özellikler göstermektedir. Bu filmler erkek çalıșmalarına ait kuramsal birikimi tartıșmak için önemli kaynaklar haline gelmektedir.

Bu makale iktidar kurmanın aracı olan "hegemonik erkeklik" kuramından yola çıkarak Korkuyorum Anne filmindeki erkeklik temsillerine odaklanacaktır. İdeal erkek kimliğinin dıșında kalarak, bu kurgusal erkek kimliğinin parçalanması filmdeki karakterler bağlamında gösterilecektir. Bu karakterler incelenirken modern ulus devletin ve ataerkil ideolojinin iktidar aracı olan kavramlardan faydalanılacaktır.

Anahtar Sözcükler: Erkeklikler, hegemonik erkeklik, beden politikaları, naif erkeklik, Reha Erdem sineması

Makale geliș tarihi: 01.04.2016 • Makale kabul tarihi: 03.08.2016

http://ilefdergisi.org/2016/3/2/

ilef dergisi • (c) 2016 • 3(2) · sonbahar/outumn: 125-142 


\section{Deconstruction of Hegemonic Masculinity in Mommy, I'm Scared}

\section{Ö. Nilay Erbalaban Gürbüz}

Gaziantep University Faculty of Fine Arts

nilayerbalaban@hotmail.com

\section{Abstract}

Gender studies have begun to focus on relationship between 'masculinity' and cultural structures since 1970s. These researches showed that not a single definition of masculinity and definition of masculinity closely intertwined with social power bonds. In Turkey cinema different masculinities have been represented since the early 2000s. These male characters are different from traditional roles of gender. These films have become important sources to discuss theoretical heritage of the masculinity studies.

This article focuses representations of masculinity in Korkuyorum Anne by use "hegemonic masculinity" theory. Characters based on film will be showed against the ideal male identity. And will be benefited notions of the modern nation-state and the patriarchal ideology of power.

Keywords: Masculinities, hegemonic masculinity, physical policies, naive masculinity, cinema of Reha Erdem. 
Gündelik hayat, kadınlık ve erkeklik rollerinin egemen toplumsal cinsiyet yaklaşımına göre yeniden üretildiği ya da karşı çıkıldı̆̆g ideolojik ve kültürel bir alandır. Feminizmin kuramsal ve mücadeleye dayalı tarihi bu toplumsal cinsiyet yaklaşımının erkek egemen ideolojik temellerini sarsmıştır. Oysa toplumsal cinsiyet rollerini belirleyen iktidarın eleştirisi, iktidarın erkek kimliği için de benzer söylemler ürettiğini ortaya koymuştur. "Cinsel karakter"1 temelli söylemler kadınları olduğu kadar erkekleri de biyolojiye dayalı psikolojik bir yapılanmaya dâhil eder. Toplumsal cinsiyet psikolojisinde yapılan araştırmaların bir bölümü de kadın ve erkek arasındaki cinsel karakter farklarını ortaya koymaya eğilimlidir. Bu araştırmalar aynı zamanda cinsiyet merkezli karakter oluşturma ve onları sabitleme gibi ideolojik bir işlev görür. Buna göre erkek çoğu zaman güçlü, duygularını kontrol eden, rekabetçi karakter özellikleri ortaya koyar. Gündelik hayatın farklı alanlarında da buna benzer bir yaklaşım benimsenir ve yeniden üretilir. Bu nedenle egemen toplumsal cinsiyet yaklaşımına göre erkeğin bu karakter özelliklerini yansıtması gerekir. Bu özellikleri yansıttığı oranda da ideal erkek tanımına uygun hale gelir. Çoğu zaman ideal erkek tanımı, gündelik hayatın içindeki diğer iktidar kaynaklarına göre yeniden biçimlenir. Her dönemin kendi egemen ideolojisiyle uyumlu, makbul bir erkeklik modeli vardır. Ancak egemen olan daima kendi muhalifini de üretir. Bu ise egemen toplumsal cinsiyete ait iktidarın 
dilini sarsar. Bu nedenle ideal erkek karakterlerin dışındaki erkeklerin görünürlüğünün artması toplumsal cinsiyete ait iktidarı tartışmaya olanak verir.

Türkiye sinemasında 2000'li yılların başından itibaren farklı erkeklik temsilleri sunan filmler çekilmiştir. Reha Erdem'in Korkuyorum Anne (2004) filmi de ideal erkek söylemini tartışmalı hale getiren bir örnektir. Filmdeki farklı erkek temsilleri erkeklikle ilgili egemen söylemi yapı bozumuna uğratır. Üstelik filmin baş erkek karakterinin hafızasını yitirmesi kültürel olarak biçimlenen erkekliğe ait rolleri unutmasına yol açmıştır. Film biyolojik olanla kültürel olanın ilişkisini izleyiciye sunar. Toplumsal cinsiyet rollerinin sadece cinsler arası değil aynı cinse ait bireyler üzerinde de kimlik teknolojilerinden biri olarak işlev gördüğü imasında bulunur.

\section{Erkek mi? Erkeklikler mi? Toplumsal Cinsiyet ve Hegemonik Erkeklik}

Toplumsal cinsiyet çalışmaları, kadın ve erkeklerin toplumsallaşırken yüklendiği rollerin çözümlenmesine dayanmaktadır. Kültürel olanla toplumsal olanın kesiştiği bir alandır. Dolayısıyla oldukça geniş bir coğrafyayı içine almaktadır. Hem ev içi hem de kamusal alanı işaret etmektedir. Her iki alanın birbirini destekler söyleme sahip olması bu noktada hayati bir önem kazanmaktadir.

Toplumsal cinsiyet çalışmaları ilk olarak kadın hakları mücadelesiyle başlamıştır. Kronolojik olarak bakıldığında yurttaşlık haklarının kazanımı için başlayan mücadele, erkek egemen toplumlarda kadın bedenine yöneltilen tahakküme karşı çıkmayı da içine alan biyopolitika alanına kadar genişlemiştir. Kadın hareketlerinin, kadınların bedenleri üzerinde iktidar kurmayı amaçlayan ve böylece sistemin yeniden üretiminin bir aracı haline gelen beden politikalarına karşı geliştirdikleri mücadele, hem teorik alanda hem de eylem alanında hala devam etmektedir. Ancak toplumsal cinsiyet çalışmalarının sadece kadın kimliği üzerinde yürütülmesinin eksikliğinin fark edilmesi erkeklik (masculinity) çalışmalarına odaklanmayı da beraberinde getirmektedir.

Ataerkil söylem, erkekliğin biyolojik tanımını sahiplenirken güç ilişkilerini muhafaza etmeyi sürdürmektedir. Çünkü biyolojik tanımlamalar erkek ve kadın bedenini toplumsal hayatta işlevselliği açısından bir referans noktası olarak alır. Bu biyolojik ve anatomik bakış açısına psikolojik yapılanma da eklenir. Oysa feminist bakış açısı Sancar'ın da özetlemiş olduğu gibi, erkekli- 
ğin de kadınlık gibi toplum ve kültür tarafından biçimlendirildiğini düşünür. “Erkeklik büyük ölçüde biyoloji, anatomi ve kısmen de psikolojinin araştırma konusu olmakla birlikte, erkekliğin toplumsal bağlamda şekillenen bir şey olduğunun kabulü ilk kez feminist kuramların sosyal bilimler alanına getirdiği bakış açısı sayesinde gerçekleşmiştir" . ${ }^{2}$ Feminist hareket içinde erkeklik tartışmaları 1970'li yıllarda başlamıştır.

1970'li yıllarda feminist mücadele içindeki tartışmalar genel bir kadın tanımının olamayacağı üzerine gelişmeye başlamıştır. Kadınlığın bir kimlik olarak toplumsal alan tarafından inşa edildiği dolayısıyla farklı kadınlık hallerinin olabileceği tartışması hem erkeklik çalışmalarının önünü açmış hem de kadın çalışmalarını toplumsal cinsiyet çalışmalarına yöneltmiştir.

Erkeklik çalışmaları içinde erkekliğin 'ne olduğu' sorusu önemlidir. Bu soru çerçevesinde erkek doğmakla erkek olmak arasındaki ilişkinin kültürel paradigmaları çözümlenir. Erkek ve erkeklik tanımı çoğul mudur, kültürel, tarihi, siyasal, ekonomik ya da etnik olarak değişkenlik gösterir mi? Toplumsal cinsiyet perspektifinden bakıldığında erkekliğin de tıpkı kadınlık gibi yaratılan bir kimlik olduğunu kabul ettiğimiz zaman, dönemsel ve kültürel erkeklik tanımlarıyla karşılaşmak mümkündür. Örneğin M.Ö. IV. ve V. yüzyıllarda Atina' da erkeklik kimliği, oikos yani hane ile kamusal alanın birbirinden kesin bir biçimde ayrılmasından izler taşır. ${ }^{3}$ Erkek olmak demek başta Atina' da doğmuş olmak, kendine ait bir toprağa sahip olmak ve kamusal faaliyetlere uyum göstermeye yetecek boş zamanı olmakla eşdeğerdir. Bu konuda zihin açıcı çalışmalardan bazılarını yazmış olan Lynne Segal, İngiltere'de XVIII. ve XIX. yüzyılda kültürel değişimin erkeklik kimliği üzerindeki etkilerini göstermiştir. Özellikle kapitalist sanayileşme döneminde burjuva aile değerlerinin şekillenmesinde rol oynayan erkek, fiziksel ve psikolojik sağlamlılığının yanı sıra iş ve aile hayatında lider özellikleriyle tanımlanmaktadır. Bu ideal erkek Amerika'da Hemingway örneğinde olduğu gibi kendi imaj kimliği ile çatışan erkekliklerin de doğmasına neden olmuştur. ${ }^{4}$ Bu burjuva erkek kimliği genel hatlarıyla tüm modern, ataerkil yapılar tarafından sahiplenilmektedir. Connell de erkeklik tanımlarının tarihsel ve toplumsal olarak değişkenlik gösterdiğini ifade ettikten sonra, XVI. yüzyıldan itibaren yaşanan siyasal ve kültürel değişimlerin erkeklik kimliğini doğrudan etkilediğini açıklar. Özellikle dört ana başlık altında toplanan gelişmeler erkeklik algısını yaratmaktadır. Bunlardan ilki Rönesans'1n etkisi, sekülerleşme ve pozitif bilimler yoluyla ortaya çıkan akılcılık ve erkeklik arasındaki ilişkinin inşasıdır. İkincisi, denizaşırı kolonyal yayılmacılığın başladığı imparatorluklar dönemidir. Üçüncüsü, 
burjuva ticareti ve kentlerin ortaya çıkışıdır. Connell dördüncü gelişmenin ise XVI. ve XVII. yüzyılda yaşanan sivil savaşlar olduğunu ifade etmektedir. ${ }^{5}$

George Lachmann Mosse ise modern burjuva erkekliğinin oluşmasında aristokratik bir gelenek olan düellonun önemine değinir. Düello yoluyla erkekler kişiselliklerini, özerkliklerini ve cesaretlerini bir erkeklik temsili olarak ortaya koymaktadırlar. ${ }^{6} \mathrm{Bu}$ kültürel ve tarihsel erkek kimliği üzerine çalışmalar bir yana, 1970'li yıllardan bu yana Kuzey Amerika'da erkeklik tartışmaları altı farklı perspektif altında devam etmektedir. Bunlar "1) muhafazakar perspektif; 2) erkek hakları perspektifi; 3) spritüel (mythopoetic) perspektif; 4) sosyalist-feminist perspektif; 5) spesifik grup perspektifi; 6) pro-feminist perspektif"dir. ${ }^{7} \mathrm{Bu}$ perspektifler içinde toplumsal cinsiyet ve LGBTİ çalışmalarıyla sıkı bir ilişki içinde olan sosyalist-feminist bakış açısı 'hegemonik erkeklik' kuramının eleştirel çözümlemesinde önemli bir rol üstlenmektedir.

Toplumsal cinsiyet çalışmaları içinde erkeklik literatürü, erkekliğin biyolojik doğaya indirilmesine, tek tipleştirilmesine olduğu kadar erkekler arasındaki hiyerarşik düzeni yaratan ve sürdüren yapıya da karşı çıkmaktadır. Erkekliğin kültürel yaşam pratikleri yoluyla örüldüğü tezi merkezi bir yerde durmaktadır.

“Erkekler ve erkeklikler üzerine eleştirel incelemeler, bir yandan ataerkilliğin bizatihi failleri olan erkekleri öznellikleri ve erkeklik deneyimleri bağlamında ayrıntılı bir biçimde incelerken, diğer yandan da erkekliği tekil ve evrensel bir fenomen olarak değerlendirmeyi bir yana bırakarak, farklı erkek olma hallerini vurgulayan 'erkeklikler' (masculinities) olarak ele alma yoluna" gider. ${ }^{8}$

Böylece erkekliğin inşasını oluşturan kodlar üzerinde durulmuştur. Bu kodların açılanmasında "hegemonik erkeklik" önemli bir anahtar kavramdır. Kavram kültür alanında erkekliğin kadınlara ve hatta bir kısım erkeklere göre niye baskın olduğunu açılamaya yaramaktadır.

Kavramı erkeklik çalışmalarında ilk kez kullanan Connell, "hegemonik erkekliği" diğerlerine karşı kazanılmış bir "güç" olarak açıklamaktadır." Acımasız iktidar çekişmelerinin ötesine geçerek özel yaşamın ve kültürel süreçlerin örgütlenmesine sızan bir toplumsal güçler oyununda kazanılan toplumsal üstünlüktür". ${ }^{9}$ Tanımdan da anlaşılacağı üzere "hegemonik erkekliğin" işlemesi ataerkil düzene ait güç ilişkilerinin yeniden üretilmesine doğrudan katkı sağlamaktadır. "Hegemonik erkeklik” pratikleri şiddeti doğrudan içermez. Hegemonya kavramını ödünç aldığı Gramsci' de olduğu gibi, hegemonya sıradan ve doğal izlenimi veren büyük bir kültür dünyası içinde kurulur. Fakat 
bu Connell'in kullandığı hegemonya kavramının güç ilişkilerinden bağımsız olduğu anlamina gelmemektedir. Hatta "hegemonik erkeklik" ve "ataerkil şiddet" arasında bir bağ vardır ve genelde ataerkil şiddet ve düzen hegemonyayı güçlendirmektedir.

Richard Howson 'hegemonik erkeklik' tartışmalarının iki yön üzerinden hareket ettiğini ifade etmektedir. İlki, iletişim araçlarında temsil edilen simgesel ideal erkek varsayımının eleştirisidir. İkincisi ise, erkeklik kimliğinin sosyo kültürel alanın içinden doğduğu saptaması üzerinden hareket eder. ${ }^{10}$ İlki, erkekliğin idealize edilmiş bir kimlik olarak inşasını ele aldığı için gerçeklik ve temsil sınırları içindeki sorunlu alanlara eğilmektedir. İkincisi, toplumsal kurumların ve gündelik yaşamın toplumsal cinsiyet rolleri açısından çözümlenmesini içermektedir. Her ikisi de ister temsilde ister pratikte olsun belli bir iktidar söylemini yıkar ve kurar. Bu iktidar, erkeğin kadınla ve erkeğin erkekle ilişkisini biçimlendirmektedir.

Howson'un ifade ettiği ideal erkek figürler, hegemonik erkek kimliğinin yaratılmasına yardımcı olmaktadır. Bu figürler kitle iletişim araçlarıyla kurulur ve ataerkil düzen içinde ideal erkekliğin hem psikolojik hem de fizyolojik özelliklerini ortaya koyar. "Aslında hegemonyanın kazanılması genellikle, Humphrey Bogart, John Wayne ve Sylvester Stallone'un canlandırdığı film karakterleri gibi tamamen kendine özgü hayal ürünü kişilikler olan erkeklik modellerinin yaratılmasını içerir". ${ }^{11}$ Alıntıdan da anlaşılacağı gibi Connell'in kavramsallaştırdığı "hegemonik erkeklik" en çok kitle iletişim araçları yoluyla üretilir. Çünkü kitle iletişim araçları aynı anda sayıca en büyük topluluğa erişebilen tek anlam taşıyıcısıdır. Üstelik Adorno' nun "kültür endüstrisi" kavramında gösterdiği gibi, kitle iletişim araçları yoluyla yaratılan "standartlaşma", "özel alan" ve "kamusal alan"ın birbirine benzemesine neden olur. Hem özel alanda hem de kamusal alanda birbirine benzer söylemler "rıza" yaratmak için dolaşıma sokulur. Rıza karşı cins için yaratılmış bir durum değildir yalnızca. Rıza tüm bir erkek egemen sistemin yeniden üretimi için yaratılmaktadır.

\section{Modern Kapitalist Devlette "Hegemonik Erkeklik" Durakları: Askerlik, Çalıșma, Güçlü Bedenler}

Sancar 'erkekliğin' inşasında askerliğin büyük bir yeri olduğunu söylemektedir. ${ }^{12}$ Askerlik eğitimi bir tür erkeklik eğitimidir çünkü. Bedenen yapılan egzersizler kadınlara göre farklı olan anatomik yapıyı güçlendirerek savaşa hazır hale getirmeye dayanır. Bedenin güçlülüğü önemlidir çünkü bu 
güç hem sivil hem de askeri hayattaki ideal erkekliğin temel tanımlarından biridir. Ülkemizde askerlik yapamayacak durumda olan erkekler için "çürüğe çıkma" teriminin kullanılması dil düzeyindeki hegemonyayı dışa vurmaktadır. Askere gitmeyenin çürük, gidenin ise sağlam olması örtük bir biçimde fallusa dayalı iktidar dilini tekrar etmektedir. Bu nedenle erkekler için askere gitme "erkeklik"lerini ispat etmenin bir sürecidir. "Adam" olma yolundaki adımlardan biridir.

Sancar militarizm ve erkeklik arasındaki ilişkiyi daha anlaşılır kılmak için askerliğini yapmış bir grup erkekle görüşmüştür. ${ }^{13}$ Görüşmelerde askeri eğitimin en önemli parçalarından birinin hiyerarşinin öğretilmesi olduğu ortaya çıkmaktadır. Ast ve üstler arasında emir-komuta zincirine dayalı bir ilişki bulunmaktadır. Bu ilişkinin öğrenilmesi askerliğin en önemli eğitimlerinden biri olarak kabul edilebilir. Bazı görüşmeciler askerliği "erkeklik" eğitiminin bir parçası olarak gördüklerini ifade etmektedir. Görüşmecilerden biri "askerlik, belki de, erkekliğe geçişte sünnetten sonra geliyor herhalde" demektedir. ${ }^{14}$ Oturuştan, kalkışa kadar erkekliğe ait bir beden dilinin öğrenildiği bir yer. ${ }^{15}$ Elias Canetti'nin iktidarın mikro kaynaklarını incelediği kapsamlı çalışmasında bir bölüm beden diline ayrılmıştır. Burada Canetti, beden dilinin itaate ve iktidara dair pek çok sembolü içerdiğini vurgulamıştır ve bu noktada askeri eğitimin bir parçası olan beden eğitiminin hem erkek kimliği hem de iktidar-itaat ilişkisi açısından önemini anlamak kolaylaşmaktadır. ${ }^{16}$ Öte yandan askerlik ideal erkek savaşçıyı yaratma süreci olmasına rağmen emir-komuta zinciri, itaatkâr erkek ve yönetici erkek kimliklerini de oluşturur. Buna erkeklik teknolojileri demek mümkündür. ${ }^{17}$

Erkeklik teknolojileri toplumsal cinsiyetin içinden hareket eder ve toplumsal kurumlar tarafından kullanılır. Erkeğin militerleşmesi, gerektiğinde silah kullanabilecek ve savaşabilecek bir duruma gelmesi değildir sadece. Hem karşı cinse hem de hemcinslerine erkekliklerini göstermelerinin bir yoludur. Öte yandan tek cinsli bir çevre olan askerlik, erkeğin diğer erkeklerle 'erkekliklerini' yarıştırdıkları mekânlar olarak değerlendirilebilir. Kışla hayatıyla baş etme pratikleri farklı erkeklik deneyimlerini ortaya koyabilir. Ömer Turan, kışladaki askerlerin deneyimlerini incelediği çalışmasında askeri pratikler ve erkeklikler arasındaki ilişkiye dair önemli bilgiler vermektedir. Kı̧̧ladaki eğitimin ideolojik içeriğini güçlü ordunun, zorunlu askerliğin ve hiyerarşik düzenin öneminin benimsetilmesi oluştururken; askerlik ve toplumsal cinsiyet arasındaki ilişki de yeniden üretilmektedir. ${ }^{18} \mathrm{Bu}$ ilişki öncelikle 'vatan borcu' anlamındaki askerliğin kadınlara ve kadınsılığa yer vermemesiy- 
le kendini göstermektedir. Arkasından ise erkeğin güçlü, dayanıklı, cesur ve korkusuz olması gerektiği öğretilmektedir.

Yukarıda Turan'ın aktarmış olduğu "disiplin ve emir komutanın gerekliliği"ne dair kışlada verilen eğitim, sivil hayatta özellikle fabrika düzeniyle karşımıza çıkan çalışma hayatının da bir parçasıdır.

“Modern çalışma düzeninde 'fabrika'nın sembolize ettiği şey, hiyerarşik bir toplumsal düzenin kendisidir ve modernite öncesi ordulara ait olan disiplin, düzene uyma ve önceden belirlenmiş, bildirilmiş eylemi gerçekleştirme nitelikleriyle donatılmıştır. Bu, militarizmin modern kapitalist toplumda sadece orduların bir karakteri olmayacağı, bizzat toplumsal düzenin yapısının militarist olması gerektiği" anlamını taşımaktadır. ${ }^{19}$

$\mathrm{Bu}$ alıntının da işaret ettiği gibi kışladaki hiyerarşik ilişkiler, idmanlar yoluyla yaratılmak istenen kuvvetli bedenler çalışma hayatının düzenine de uymaktadır. Clastres, Batının toplumsal hayatını belirleyen iki aksiyomu, çalışma ve devletin varlığı olarak ifade eder. ${ }^{20}$ Ataerkilliğin en önemli kaynağ ise toplumsal cinsiyete dayalı işbölümüdür. Özellikle mekânlara dayanan bu iş bölümünde erkeklerin özel hayattaki iktidarı, kamusal hayattaki çalışma yaşamında kadınlardan daha çok yer almalarıyla ilgilidir. Öte yandan böylesi bir vurgu erkeklik kimliği ile çalışma arasındaki ilişkiyi de içine almaktadır. Erkeklikler çalışmayla ilgili olarak tanımlanır ve erkeklikle çalışma arasında doğrudan bir bağlantı kurulur. ${ }^{21}$ Erkekler çalışma hayatına katılarak hane içindeki 'evin reisi' olma statüsünü korur. Özel alanda 'evin reisi' olarak beliren iktidar, kamusal alanda da erkekler arası ilişkilerde mesleklerle bağlantılı bir iktidar modelini ortaya koymaktadır. Kazancı ve meslek saygınlığı yüksek olan erkek, karşı cins için olduğu kadar hemcinsleri açısından da "ideal" olanı yansıtmaktadır. Beyaz, orta sınıf erkek, ideal bir erkek temsili olarak kültürel anlamda gündelik hayata dâhil edilir.

"Hegemonik erkek" kavramının diğer erkeklerle olan ilişkide belli bir güç ve otorite kazanımı olduğuna yukarıda değinmiştik. Bu güç toplumsal ve kültürel yapı tarafından belirlenmektedir. Bu nedenle erkeğin diğer erkeklerle olan ilişkisinde hegemonya araçlarının değişkenlik gösterebileceğini de akılda tutmak gerekmektedir. Yine de bütün kapitalist toplumlarda burjuva erkek modeline yaklaştıkça kazanılan bir hegemonyanın varlığı aşikârdır. Bu erkek kimliğinin özelliklerinden biri de sağlıklı bir beden yapısına sahip olmaktır. Sporla uğraşmak, güçlü bir bedene sahip olmak burjuva ideal erkeği için teşvik edilmektedir. Zaten erkeklik "stereotipi" de erkek anatomisinin doğasıyla önemli bir ilişki içindedir. ${ }^{22}$ 
İdeal beden aynı zamanda politikleşmiş ve militerleşmiş bir bedendir. Çünkü ideal olan sistem tarafından tarif edilendir. Yiğit Akın'ın Türkiye Cumhuriyeti'nin ilk yıllarında beden terbiyesini incelediği çalışması bu ilişkiyi kendi tarihimizden anlatmaktadır. "Militarize bir fiziki kültür vurgusu erken Cumhuriyet döneminin bütün beden terbiyesi ve spor alanını kaplamış durumdadır" ${ }^{23}$ Buradaki beden terbiyesinde bazı spor dalları diğerlerine göre tercih edilmektedir ve bunun nedeni, toplumsal olarak ihtiyaç duyulan yeni neslin yaratılmasına katkısıdır. Konumuz açısından ele alırsak ideal bedenin politik beden olmasının nedeni sistemle kurulan ilişkisinden doğmaktadır. İdeal erkek bedeni için de aynı ilişkinin kurulabileceğini savunuyoruz. İdeal erkek bedeni kapitalizmin üretkenlik açısından değerlendirebileceği beden olmalıdır.

Türkiye sinemasının tarihinde asker karakterlerin başrol üstlendiği filmler azımsanmayacak sayıdadır. Kimi zaman tarihsel savaşların içinde, kimi zaman ise melodramlarda asker figürü sıklıkla karşımıza çıkar. Bu filmlerdeki karakterler kendi türleri içinde ya milli duyguların inşasına hizmet eder ya da bir aşk ilişkisi içinde gösterilir. Bazı dönemlerde ülkenin uluslararası ilişkilerinde yaşanan gelişmeler askerlik, vatan savunması üzerine filmlerin yapılmasının toplumsal zeminini oluşturmuştur. Kore Savaşı, Kıbrıs meselesi, azınlıklarla ilişkiler sadece bu konular üzerine bir dizi film yapılmasına sebep olmuştur. Bu filmlerin çoğunda halk kahramanı erkek askerler düşmanla çatışmaktadır. Bu çatışma yalnızca düşman olan tarafla çatışmayı değil, içerden gelen hain kişilere karşı da temkinli olmayı kapsamaktadır. Bu hain karakterler genellikle eksik erkek olarak tanımlanmaktadır. Bir erkeğin sahip olması gereken cesarete ve yiğitliğe sahip olmadıkları için ideal erkek temsilinin d1şında karakterlerdir. Genelde yan rollerde yer alan bu karakterler, izleyicilere milli duyguları olmayan bir erkeğin 'erkek' de olamayacağı mesajını verir.

Hilmi Maktav Türkiye sinemasının 'askeri' tarihini incelediği çalışmasında, sinemamızdaki askerlerin ideal bir erkek karakter olarak göründüğünü söyler. Bu ideal karakter milli değerleri olumlamanın da bir yoludur.

“Erkek kahramanı özenilen, güçlü bir figür yapmak için kullanılan namus, şeref, cesaret gibi özellikler aynı zamanda Türk toplumunun askerliğe atfettiği değerler olduğu için, askere giden kahraman bütün bu değerleri doğal olarak üzerinde taşımaktadır; askerlik, bir Türk erkeği olarak doğasında zaten var olan olumlu vasıfları daha da güçlendirip, onu tam anlamıyla bir kahraman haline getirirken, bu inşanın gerçek mimarı olan ordu da yüceltilmiş olur, askerliğin gerekliliği bir kez daha onaylanır". ${ }^{24}$ 
Yakın dönem Türkiye sinemasında Yazı Tura (Uğur Yücel, 2004), Korkuyorum Anne (Reha Erdem, 2004), Zenne (M.Caner Alper-Mehmet Binay, 2012) gibi filmler dışında askerlik ve erkeklik arasındaki ilişkinin hep tek bir biçimi işlenmiştir. Yukarıda anılan filmlerde ise hem savaş milliyetçiliğinin hem de 'ideal erkek' söyleminin eleştirisi yapılmaktadır. Yazı Tura' da askerliğini Güneydoğu'da yapmış iki gazinin sivil hayata alışamaması, militarizm ve erkeklik arasındaki bağın sorunlu doğasına göndermede bulunur. Ahmet Oktan, filmdeki baş karakterlerin bedensel ve psikolojik olarak aldıkları yaralar nedeniyle sivil hayatta "erkeklik krizi" yaşayan erkekler olarak düşünülmesi gerektiğini ifade etmektedir. ${ }^{25}$ Korkuyorum Anne' de askerlikten korkan yetişkin bir erkeğin içinde bulunduğu ruh hali, trajikomik bir biçimde yansıtılmıştır. Son film ise gey bir erkeğin hem günlük yaşamda hem de askerlik kurumuyla olan ilişkisinde yaşadıklarını anlatmaktadır. Gey karakterin "çürük" raporu alma sırasında yaşadığı aşağılanmalar, annesinin korkuları, askerliğini yaptıktan sonra savaşın ruh halinden kurtulamayan ağabey, filmde yer almaktadır. Sinemada bilinen asker karakterlerin dışında karakterlerin gösterilmesi önemlidir. Bu karakterlerin görünür kılınması hegemonik erkeklik kimliğine karşı verilmiş mücadelelerin bir parçasıdır. Türkiye'de toplumsal cinsiyet araştırmalarının bir parçası olarak 'erkeklik' çalışmaları 2000'li yılların ortalarında yapılmaya başlanmıştır. Ancak 1980'den itibaren gelişen kadın hakları mücadelesinin kazandırmış olduğu deneyim ve 2000'li yıllarda militarizm üzerine yapılan araştırmalar, 2000'li yıllardan sonra çekilen ve yukarıda adı anılan filmlerin içeriğini dolaylı olarak etkilemiştir. Bu durum, 1980'li yıllarda başlayan feminist mücadelenin Türkiye sinemasında pro-feminist filmlerin çekilmesindeki etkisine benzer bir etkidir. Erkek bedenine yöneltilmiş tahakkümcü kimlik politikalarına karşı yapılacak eleştirilerin pek çok çeşidi olabilir. Bunlardan biri de farklı erkekliklerin kamusal alandaki varlıklarını görünür kılmaktan geçmektedir.

\section{Korkuyorum Anne Filminde Hegemonik Erkekliğin Yapı Sökümü}

Reha Erdem'in yönetmenliğini yaptığı Korkuyorum Anne, farklı erkeklik temsillerinin yer aldığı bir filmdir. Bir soygunun şüphelilerinden olan Ali (Ali Düşenkalkar) karakteri geçirdiği trafik kazası sonucu hafızasını yitirir. Babası ve komşularının yardımıyla hafızasının geri gelmesi için çabalayan Ali, hayat ve insanlar hakkında yeni bilgiler edinmeye başlar. Zaten filmin uluslararası İngilizce alt başlığı "İnsan Nedir ki?" bu noktada filmin temel vurgusunu yapmaktadir. 
Film, adından da anlaşılacağı üzere insana dair bir duygu olan korkuya odaklanmaktadır. Çocukluk ve yetişkinlik dönemi boyunca yaşadığımız korkuların toplumsal ve kültürel kaynakları filmdeki karakterler tarafından açığa çıkarılmaktadır. Korkuyorum Anne'de ideal erkek temsilleri ve ideal erkek temsilinin dışında değerlendirilecek erkek karakterler film boyunca bir arada bulunurlar. Ali, Ali'nin babası Rasih (Köksal Engür), Keten (Turgay Aydın), kasap (Bülent Emin Yarar), Aytekin (Aydoğan Oflu), küçük Çetin, yaşları, meslekleri, korkuları ve istekleri birbirinden farklı erkek karakterlerdir.

Hafızasını kaybeden Ali yarı çocuksu bir erkek karakter olarak filmde yer almaktadır. Hafıza ve kimlik arasında doğrudan bir ilişki olduğunu düşünürsek aslında Ali ve küçük Çetin arasında bir ortaklık olduğunu söyleyebiliriz. İkisi de yetişkinler dünyasında yetişkin olmayan, kimlik edinme sürecinde kültür tarafından toplumsal cinsiyet rolleri öğretilen öznelerdir. Ali, kendisini küçümseyen, beklentileri karşılanmadığı için kendisini suçlayan babayı hatırlamayı reddeder. Çünkü baba tarafından oğluna biçilen kimlik, toplumsal cinsiyet rollerinden geçer. Baba, oğlunun hep tembel ve işe yaramaz olduğunu, bir erkek olarak kendisinden beklenilenleri yerine getiremediğini ve hafiza kaybının da bunun bir parçası olduğunu iddia eder. Oysa Ali'nin babasını hatırlamayışı ve babasının kendi üstündeki her türlü otoritesini reddetmesi 'babalık krizi'ne yol açan bir eylem anlamına gelir. ${ }^{26}$ Lacancı açıdan kültür tarafından oluşturulan 'simgesel baba' yıkılır. Lacancı psikanalizde çocuk dış dünyayla simgeler (dil) yoluyla iletişim kurar ve bu simgeler aracılığıyla biçimlenir. Çocuk simgeler yoluyla kendini tanımlar ve kurarken bir yandan da ödipal ilişkilerin içinden geçer. Kültürel bir alan olan simgesel düzen içinde 'baba' figürü de otorite ve yetkiye göndermede bulunur. 'Simgesel baba' doğrudan bir baba figürüne gönderme yapmaz. Daha çok kültürel bir iktidarı temsil eder. Lacan "babalığın özünde biyolojiyi aşan bir niteliğinin” olduğunu söyler. ${ }^{27} \mathrm{Bu}$ bakımdan Ali'nin 'simgesel babayı' tanımayışı, 'babalık' rolünün altında bulunan ve toplumsal cinsiyete ait geleneksel kodları taşıyan kültürü yapı bozumuna uğratma girişimidir.

Sağlıkçı olan babanın hayat felsefesi insan anatomisinin doğru kullanılmasında yatmaktadır. İnsan anatomisi ve bedeniyle toplumsal cinsiyet ve militarizm arasındaki bağ bütün modern ulusal devletlerin kuruluşunda devlet kurumlarının üzerinde önemle durdukları bir konu olmuştur. Bedenin 'terbiyesiyle' kültürün cinsiyetçi rolleri arasındaki ilişki modern kapitalist uygarlığın işlevselci zihniyetine dayanmaktadır. Sancar bedenin ve sağlığın "bir tür fiziki sermaye (Bourdieucü anlamda)"”28 olarak algılandığını ifade eder. 
Bu bağlamda sağlıklı beden, ideal ve kapitalizm için üretken erkek yurttaşın önemli bir niteliği olarak kabul edilir. Fabrika düzeniyle uyumlu hale getirilmeye çalışılan toplumsallıkta her yurttaş sistem için yararlı bireyler haline getirilmelidir ve cinsiyet rolleri de bunu içine almaktadır. Zaten klasik anlamdaki ataerkillik bu işlevselci yapıyı cinsiyetçi iş bölümüne yüklemektedir. ${ }^{29}$ Oysa Ali karakteri, bu kimliği reddetmesinin simgesel dışavurumunu babayı hatırlamayarak gerçekleştirmektedir. Diğer taraftan erkeklik teknolojilerinin kültürel ve toplumsal duraklarından olan sünnet ve askerlik fotoğrafları karşısındaki tepkisi de bu perspektiften düşünüldügünnde anlam taşımaktadır. Baba tarafından Ali'ye yaptırılan hafıza egzersizlerinde Ali, kendisine gösterilen sünnet fotoğrafında acıyı anımsarken, askerlik fotoğrafında ise "kendisinin orada olmadığını" söyleyerek tepki verir. Ali, toplumsal ve kültürel olarak anlamları sabitlenmiş bu iki örnek karşısında cinsiyetçi değil, insanî tepkiler vermektedir. Belleğini yitirmiş olması, kültürel olarak sabitlenmiş anlamları hatırlamayarak insani ve doğal olanın ortaya çıkmasını sağlamaktadır.

Filmin bir diğer erkek karakteri Keten de Ali gibi ebeveyni tarafından kendisine yüklenen görevleri yerine getirmediği için hor görülmektedir. Keten, terzi olan annesi tarafından yeterince 'erkek' olamadığı için örselenmektedir. Onun varlığı 'erkeklik' rollerini yerine getiremeyen bir erkek olduğu için bizzat annesi tarafından reddedilir. Hem 'baba' figürünün eksikliği hem de 'yeterince erkek' olamayan oğul nedeniyle anne eril bir kimliği benimsemek zorunda kalmıştır. Korkuyorum Anne' de "erkek karakterlerin aşırı otoriter erkekler ya da tâbi erkekler olmak üzere ikili bir bakış doğrultusunda ele alınması karşısında kadın karakterler, erkeklerden yardım almaksızın kendi ayakları üzerinde duran, güçlü, bağımsız, kararlı, aktif kadınlar olarak sunulurlar. ${ }^{30}$ Bu nedenle Keten' in 'eril' anneye tepkisi uykusunda yatağını ıslatmasıyla sembolikleşir. Ali'nin babaya, kendisini hatırlamayarak verdiği tepki, Keten' in yatağına işemesiyle aynı kaynaktan beslenmektedir. Keten'in annesi de tıpkı Ali'nin babası gibi mesleği nedeniyle insan anatomisiyle ilgilenmektedir. Mükemmel, işlevsel ve cinsiyetçi bedenlere olan övgü, kaynağını ataerkil kapitalist uygarlıktan alır ve biyo-iktidar pratikleriyle uygulanır.

“İnsan bedeni, onun derinlerine inen, eklemlerini bozan ve onu yeniden oluşturan bir iktidar mekanizmasının içine girmektedir. Aynı zamanda bir 'iktidar mekaniği' de olan bir 'siyasal anatomi' doğmaktadır, bu anatomi başkalarının bedenlerine, yalnızca onların istenilen şeyleri yapmaları için değil, aynı zamanda öyle istenildiği üzere, hız ve etkinliğe uygun olarak belirlenen tekniklere göre iş görmeleri için nasıl el konulabileceğini tanımlamaktadır". ${ }^{31}$ 
Ali ve Keten, cinsiyetçi iş bölümü tarafından biyolojik doğalarını tahakküm altına alarak kendilerine "erkek" diye seslenen yapıya kendi 'doğaları' içinden karşı çıkmaktadır. Duygusallıktan uzak ve akılcı olarak tarif edilen bir cinsiyetin üyesi olarak tepkilerini yönlendiren kaynaklar duygusallıktır. Goldberg erkeğin, “kabul edilebilir 'erkekçe' tarzında davranabilmesi için duygularını ve insanca ihtiyaçlarının neredeyse tamamını bastıracak ve yadsıyacak şekilde toplumsallaştırılması nedeniyle uyuşturulmuş ve robotlaştırılmış" olduğunu söylemektedir. ${ }^{32}$ Bu açıdan düşünüldüğünde Ali ve Keten karakteri ideal erkek kimliğinin dişında erkeklik özellikleri göstermektedir.

Ali ve Keten'in dışında filmdeki diğer erkek karakter Aytekin'dir. Aytekin askerlikten korkar ve askerliğe elverişsiz olduğunu ispat etmeye çalışır. “Gündelik hayattaki erkeklik 'mikrokültürü'nün, milliyetçiliğin, özellikle de milliyetçiliğin militarist yanının talepleriyle pekala uyuştuğu" önermesi ve askerliğin hem erkeklik teknolojilerinin en önemlisi hem de ulus devletin önemli bir dayanağı olması düşünüldüğünde Aytekin normatif erkek/ ideal erkek tanımlamasının dışında kalmaktadır. ${ }^{33} \mathrm{O}$ da, Ali ve Keten gibi cinsiyetçi kimlik modeline uymaya direnmektedir. Açık bir biçimde askerlikten korktuğunu bir başka erkek arkadaşıyla paylaşmaktan çekinmez. Sünbüloğlu'nun işaret ettiği gibi, "Mehmetçik soyutlamasının dikkatlerden kaçırdığı askerlik bağlamında yaşanan korkuların, endişelerin, sıkıntıların ve maruz kalınan şiddetin ve bunlara karşı geliştirilen direniş stratejilerinin görünür hale gelmesi erkeklerin hangi şartlar altında ve ne dereceye kadar kendilerinden beklenen davranışları gösterdiklerini daha iyi anlamaya yardımcı olacaktır."34 Bu bağlamda kültürel olarak benimsenmiş bir erkeklik durağı olan askerliğe gitmekten korkmanın temsili, 'başka bir erkeklik' halinin de temsilidir. Kültürel olarak sünnet ve askerlikten sonra evlenip 'baba' olmayla devam eden erkeklik yolculuğunun bir başka rotası çizilmektedir. Aytekin bu geleneksel erkeklik pratiklerini yıkmaya çalışır ve bunu arkadaşı Ali'den gizlemez. Filmde Aytekin'in sevgilisiyle kurduğu ilişkinin varlığı ve askere gitmek istemeyişinin gizlenmemesi, askere gitmekten duyulan korkunun 'erkekliğe halel getireceğini' benimsemiş bir kültürün dışından konuşmaktır. Böylece, sistemin bir erkeklik öznesi yaratmak için kullandığı pratiklere Althusserci anlamda düşünürsek cevap verilmemektedir. Althusser'in “özne kategorisi her ideolojinin kurucu kategorisiyse bu, her ideolojinin (her ideolojiyi tanımlayan) işlevinin somut bireyleri özne haline getirmek olmasındandır" önermesini unutmayalım. ${ }^{35} \mathrm{Bu}$ bağlamda Aytekin ve filmdeki diğer erkek karakterlerin varlığı geleneksel olarak sabitlenmiş erkeklik kodlarının ve buna dayalı 'erkek' olarak öznelik hallerinin reddinin temsilidir. 
Filmde mahalle kasabının temsil ettiği 'erkeklik', mesleklerin cinsiyete dayalı iş bölümünü görünür kılan bir başka göstergedir. "Kasaplık mesleğinin maço yanı sıklıkla sinema temsillerine de yansıtılmıştır. Özellikle Yeşilçam melodramlarında kasapları sert, tutucu ve maço aile babaları olarak görmemiz mümkündür." ${ }^{36}$ Kasaplık mesleği kadınların 'naifliği' yerine antropolojik tarihin derinlerinden seslenen ve erkeğe yakıştırılan 'avcılık' uğraşısının modern bir uzantısıdır neredeyse. Mahalle kasabı bunun farkındadır ve başta Ali olmak üzere etrafındaki erkeklere 'erkek' olmak üzerinden ders vermeyi ihmal etmez. Ali'ye bir kadının karşısında 'nasıl' durması gerektiğini, küçük Çetin'e de sünnetten korkmaması gerektiğini söyler. Ancak bütün bu geleneksel erkeklik algısına rağmen kasabın da korkuları vardır. Komşusunun köpeğini hiç sevmemesinin nedeni ondan korkmasıdır ve köpekten kurtulma görevini kendi üzerine aldığında bu ortaya çıkar. Ancak bir 'erkek' olarak bunu kendisine ve komşularına açıklayamamaktadır.

Filmin ana oyuncularından olmayan ancak bir kaç sahnede yer alarak 'başka bir erkeklik hâli'ni temsil eden diğer karakterler de apartman görevlisi ve arkadaşlarıdır. Kendilerine emanet edilen köpekleri bir yere bağlayarak kahvedeki sohbetlerine tanık olduğumuz bu karakterler, sahip oldukları hastalıklar ile birbirleriyle bir prestij mücadelesine girmektedirler. En çok hastal1ğı olan kişi saygıyı ve ilgiyi en fazla hak eden olacaktır. Bu sahnenin içeriğinin folklorik bir yurttaşa mı yoksa eleştirel bir sağlık fetişizmine mi gönderme yaptığını anlamak zor görünmektedir. Ancak, konumuz bağlamında sahnenin içeriğini okuduğumuzda bedenle ilişkisi kurulan ideal erkek tanımının burada da parçalandığını söylemek mümkündür. Zira "erkeklerin bedenlerinin güçlü görünmesini gölgeleyecek hastalık, sakatlık, şişmanlık benzeri halleri 'erkeklik aşınması' olarak algılayıp bu tür durumlarda sorunlar yaşadıkları ve bunları konuşmakta zorlandıkları" erkeklik üzerine yapılan araştırma sonuçlarından biridir. ${ }^{37}$ Hastalıklarıyla övünen bu bedenler modern iktidarın sağlık ve ideal erkeklik söylemini parçalamaktadır.

\section{Sonuç}

Hegemonik erkeklik kültürel bir yapılanmadır. İdeal bir erkekte bulunması gereken özellikler, kültüre ait iktidar kurumları tarafından belirlenir. Yaşadığımız modern sınıflı toplum içinde ideal erkek, bu toplumsal yapının kurumlarına hizmet edecek nitelikleri taşımak zorundadır. Üretken, toplumsal cinsiyet rollerini içselleştirmiş, toplumsal hiyerarşi kurallarına uyan sağlıklı bir erkek, ideal bir erkek temsilidir. Oysa sınıflı toplumun çelişkileri toplumsal cinsiyet hakkındaki sabit yargıları da sarsmıştır. Popüler kültürde de 
ideal erkek kimliğine ait nitelikler taşımayan erkeklerin görünürlüğü gittikçe artmıştır. 2000'li yıllardan sonra Türkiye sinemasında çeşitli erkeklik halleri görünmeye başlamıştır. Bu erkeklik temsilleri, bazı filmlerde toplumsal cinsiyet rollerine ait değerlerin değişiminden kaynaklanan bir krizin habercisi olmuştur. Bazı filmlerde doğrudan bu değerlerin eleştirisini yapmaya olanak sağlayacak bir biçimde oluşturulmuştur.

Korkuyorum Anne filminde yer alan erkek karakterler, geleneksel ataerkil cinsiyet rollerini ve aynı zamanda burjuva ataerkilliğinin temsil ettiği ideal erkek kimliğini reddeden özneler olarak karşımıza çıkmaktadır. Film, beden sağlığına, kültürel ritüellere, modern dünyanın çalışma ideolojisine de dayanarak kurulan ve yüceltilen erkekliklerin yerine hem anatomik hem de kültürel olarak bu normların dışında kalmış erkekliklere odaklanmaktadır. Bu karakterler insani duygularıyla filmin içinden seyircisine seslenmektedir. Korkuları, aşkları ve kaygılarıyla hegemonik seslenişi görmezden gelerek, erkek olmanın başka hallerini temsil etmektedirler. 


\section{Notlar}

1 Reawyn W. Connell, Toplumsal Cinsiyet ve İktidar, çev. Cem Soydemir ( İstanbul: Ayrıntı Yayınları, 2016), 245.

2 Serpil Sancar, Erkeklik: İmkansız İktidar (İstanbul: Metis Yayınları, 2011), 24.

3 Henrik Berg, "Masculunities in Early Helenistic Athens," What is Masculunity? Historical Dynamics from Antiquity to Contemporary World içinde, ed. John H. Arnold ve Sean Brady (New York: Palgrave Macmillan, 2011), 100.

4 Lynne Segal, "Yarışan Erkeklikler: Erkeklik-Erkek İdeali," çev.Volkan Ersoy, Birikim Dergisi, erişim tarihi 10 Mart 2015, http:/ / www.birikimdergisi.com/birikim-yazi/5636/yarisan-erkeklikler-erkeklik-erkek-ideali\#.Vv275OLhDIU

5 Raewyn W.Connell, Masculinities (Cambridge: Polity Press, 2005), 186-189.

6 George Lachmann Mosse, The Image Of Man: The Creation Of Modern Masculinity (New York: Oxford University Press, 1996), 18.

7 Berfin Emre Çetin, The Paramilitary Hero on Turkish Television: A Case Study on Valley of The Wolves (Newcastle: Cambridge Scholars Publishing, 2015), 43.

8 Mehmet Bozok, “Feminizmin Erkekler Cephesindeki Yankıs1," Cogito 58 (Bahar, 2009): 274.

9 Connell, Masculinities, 246.

10 Richard Howson, Challenging Hegemonic Masculinity (London: Routledge, 2006), 7.

11 Connell, Masculinities, 247.

12 Sancar, Erkeklik, 153.

13 Sancar, Erkeklik, 158-174.

14 Sancar, Erkeklik, 168.

15 Sancar, Erkeklik, 164-165.

16 Elias Canetti, Kitle ve İktidar, çev. Gülşat Aygen (İstanbul:Ayrıntı Yayınları, 1998), 383-391.

17 V.Spike Peterson, "Gendered Identities, Ideologies and Practices in the Context of Warand Militarism," Gender, War and Militarism: Femist Perspective içinde, ed. Laura Sjoberg ve Sandra Via (Connecticut: Greenwood Publishing Group, 2010), 23.

18 Ömer Turan, “Esas Duruş!: Kışla Deneyimleri ya da Türkiye'de Zorunlu Askerliğin Antropolojisi," Erkek Millet Asker Millet Türkiye'de Militarizm, Milliyetçilik Erkek(lik)ler içinde, der. Nurseli Yeşim Sünbüloğlu (İstanbul: İletişim Yayınları, 2013), 316.

19 Nilgün Toker, “Cinsiyetçilik Her Zaman Militarist Mi?," Amargi Dergi, (2007) : 37.

20 Pierre Clastres, Devlete Karşı Toplum, çev. Mehmet Sert ve Nedim Demirtaş (İstanbul: Ayrıntı Yayınlar1, 2011), 155.

21 Chris Haywood ve Mairtin Mac an Ghill, Men and Masculinities (Buckingham: Open University Press, 2003), 21. 
22 George Lachman Mosse, The Image Of Man: The Creation Of Modern Masculinity (New York: Oxford University Press, 1996), 6.

23 Yiğit Akın, Gürbüz ve Yavuz Evlatlar: Erken Cumhuriyet'te Beden Terbiyesi ve Spor (İstanbul: İletişim Yayınları, 2004), 153.

24 Hilmi Maktav, Türkiye Sinemasında Tarih ve Siyaset (İstanbul: Agora Kitaplığı, 2013), 8.

25 Ahmet Oktan, “Türk Sinemasında Hegemonik Erkeklikten Erkeklik Krizine: Yazl-Tura Ve Erkeklik Bunalımının Sınırları," Selçuk İletişim Fakültesi Dergisi 5/ 2 (2008): 153.

26 Eren Yüksel, “2000’ler Türkiye Sinemasında Erkeklik Krizi ve Erkek Kimliğinin İnşası” (doktora tezi, Ankara Üniversitesi, 2013). Yök Ulusal Tez Merkezi. https: / / tez.yok.gov.tr/UlusalTezMerkezi/tezSorguSonucYeni.jsp, 151.

27 Jacques Lacan, Psikanalizin Dört Temel Kavramı, çev. Nilüfer Erdem (İstanbul: Metis Yayınları, 2013), 262.

28 Sancar, Erkeklik, 253.

29 Deniz Kandiyoti, Cariyeler Bacılar Yurttaşlar: Kimlikler ve Toplumsal Dönüşümler, çev. Şirin Tekeli vd. (İstanbul: Metis Yayınları, 1997), 170.

30 Eren Yüksel, “2000’ler Türkiye,” 170.

31 Michel Foucault, Hapishanenin Doğuşu, çev. Mehmet Ali Kılıçbay (Ankara: İmge Yayınları, 2000), 211.

32 Herb Goldberg, Erkek Olmanın Tehlikeleri, çev. Selçuk Budak (Ankara: Öteki Yayınları, 1992), 67.

33 Joanne Nagel, “Erkeklik ve Milliyetçilik: Ulusun İnşasında Toplumsal Cinsiyet ve Cinsellik,” Vatan, Millet, Kadınlar içinde, der. Ayşegül Altınay (İstanbul: İletişim Yayınları, 2004), 79.

34 Nurseli Yeşim Sünbüloğlu, "Sürüne Sürüne Erkek Olmak: Normatif Erkekliğin Kurucusu Olarak Askerlik," 2009: 10, http://www.academia.edu/3346241/_S\%C3\%BCr\%C3\%BCne_ S\%C3\%BCr\%C3\%BCne_Erkek_Olmak_Normatif_Erkekli\%C4\%9Fin_Kurucusu_Olarak_Askerlik_2009_B. Erişim tarihi: 02.01.2016.

35 Louis Althusser, İdeoloji ve Devletin İdeolojik Aygıtları, çev. Mahmut Özışık ve Yusuf Alp (İstanbul: İletişim Yayınları, 2000), 60-61.

36 Uğur Ferhat Korkmaz, "Parisli Bir kasabın Erkeklik Halleri," Ankara Üniversitesi İlef Dergisi 1, (2014): 96.

37 Sancar, Erkeklik, 253. 